\title{
Rice Bran as a Substrate for Proteolytic Enzyme Production
}

\author{
Alagarsamy Sumantha ${ }^{1}$, Paul Deepa ${ }^{1}$, Chandran Sandhya ${ }^{1}$, George Szakacs $^{2}$, Carlos \\ Ricardo Soccol ${ }^{3}$ and Ashok Pandey ${ }^{*}$

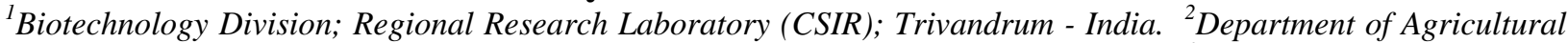 \\ Chemical Technology; Technical University of Budapest; Budapest - Hungary. ${ }^{3}$ Laboratório de Processos \\ Biotecnológicos; Universidade Federal do Paraná; Curitiba - PR - Brasil
}

\begin{abstract}
Rice bran was used as the substrate for screening nine strains of Rhizopus sp. for neutral protease production by solid-state fermentation. The best producer, Rhizopus microsporus NRRL 3671, was used for optimizing the process parameters for enzyme production. Fermentation carried out with $44.44 \%$ initial moisture content at a temperature of $30{ }^{\circ} \mathrm{C}$ for $72 \mathrm{~h}$ was found to be the optimum for enzyme secretion by the fermenting organism. While most of the carbon supplements favored enzyme production, addition of casein resulted in a marginal increase in protease yield. Fermentation was then carried out under optimized conditions to obtain the crude extract of the enzyme, which was partially purified by precipitation and dialysis. A 3-fold increase in the enzyme purity was achieved in this manner. The enzyme was found to be a metalloprotease, being activated by $\mathrm{Mn}^{2+}$, with maximal activity at a temperature of $60{ }^{\circ} \mathrm{C}$ and $\mathrm{pH} 7.0$.
\end{abstract}

Key words: Solid-state fermentation, Rice bran, Rhizopus, neutral protease, agro-industrial residues

\section{INTRODUCTION}

Rice bran is a by-product of the rice milling industry. In India, nearly one million tons of bran is produced every year. It has a high nutritive value and serves as a valuable feed for cattle, poultry, and pigs. Rice bran supplies almost the same amount of protein (10-15\%) as wheat and oats and its protein is of considerably better quality than maize (The Wealth of India, 2001). Rice bran has been used as a fermentation substrate for the production of enzymes such as lipase by Candida sp. (Rao et al., 1993a; b), in combination with cassava starch and rice hulls for the production of glucoamylase by Aspergillus sp. (Tani et al., 1986) and also with wheat bran for the production of alkaline protease by Trichoderma koningii (Manonmani and Joseph, 1993).
Proteases are proteolytic (protein-digesting) enzymes that are mainly classified on the basis of their $\mathrm{pH}$ optimum as acidic, neutral, and alkaline proteases. These biocatalysts find wide applications in many industries such as textile, laundry, healthcare etc. Neutral proteases are mainly used in food processing such as baking, brewing, and also in the healthcare sector. One of the more recent applications of these proteases exploit their eco-friendly nature and hence their suitability to act as food-processing aids, wherein these enzymes can be used for the extraction of plant oils thus largely replacing hazardous organic solvents such as hexane which has been traditionally used for such processes.

Neutral protease production has been carried out under both submerged $(\mathrm{SmF})$ and solid-state fermentation (SSF) using substrates such as wheat

${ }^{*}$ Author for correspondence 
bran (Fernandez-Lahore et al., 1998; Couri et al., 2000; Sandhya et al., 2005), steamed rice (Chou and Rwan, 1995), mango peel and banana peel (Couri et al., 2000), etc. Fermentation of rice bran by Rhizopus sp. has been reported, but only for the production of acid protease (Ikasari and Mitchell, 1996; 1998). There are no reports on the production of neutral protease by Rhizopus sp. Hence, the potential of rice bran to be used as a substrate for the production of neutral protease by Rhizopus sp. was investigated.

\section{MATERIALS AND METHODS}

\section{Substrate}

The substrate used in this study, rice bran, was obtained from a local market in Trivandrum.

\section{Microorganism and maintenance of culture}

The Rhizopus strains, $R$. oligosporus NRRL 2710, 5905, $R$. microsporus NRRL 3671, $R$. oryzae NRRL 1526, 1891, 6431, 395, 3562, 1472 were obtained from Northern Regional Research Laboratory, USA and grown on Potato Dextrose Agar (PDA) slants at $30{ }^{\circ} \mathrm{C}$ with fortnightly transfer to fresh medium.

\section{Inoculum preparation}

The inoculum was prepared by dispersing the spores from a week-old fungal slant culture in 0.1 $\%$ Tween- 80 solution with a sterile inoculation loop.

\section{Solid-state fermentation}

Five grams of rice bran was taken in a $250 \mathrm{ml}$ Erlenmeyer flask, moistened with salt solution [composition $(\% \mathrm{w} / \mathrm{v})$ : ammonium nitrate 0.5 , potassium dihydrogen orthophosphate 0.2 , sodium chloride 0.1 , and magnesium sulphate 0.1 ] to achieve the desired moisture content, sterilized at $121.5{ }^{\circ} \mathrm{C}$ for $15 \mathrm{~min}$, cooled, inoculated with $1 \mathrm{ml}$ of fungal spore suspension $\left(10^{6}\right.$ spores $\left./ \mathrm{ml}\right)$ and incubated at $30{ }^{\circ} \mathrm{C}$ for $72 \mathrm{~h}$, unless otherwise mentioned. All experiments were carried out in two sets. The results shown are average values \pm SD.

\section{Extraction of crude enzyme}

A solution of Tween-80 (0.1\%) in distilled water was added to the fermented substrate and the substrate was homogenized on a rotary shaker at
$180 \mathrm{rpm}$ for $1 \mathrm{~h}$. The solids were removed by centrifuging the homogenate at $8000 \mathrm{x} g$ at $4{ }^{\circ} \mathrm{C}$ for $15 \mathrm{~min}$ and the resultant clear supernatant was used for analytical studies.

\section{Analytical methods \\ Assay for neutral protease}

To $200 \mu \mathrm{l}$ of crude enzyme extract, $500 \mu \mathrm{l}$ of casein $(1 \%)$ and $300 \mu \mathrm{l}$ of $0.2 \mathrm{~mol} / \mathrm{l}$ phosphate buffer ( $\mathrm{pH}$ 7.0) were added. The reaction mixture was incubated at $60{ }^{\circ} \mathrm{C}$ for $10 \mathrm{~min}$ and arrested by the addition of $1 \mathrm{ml}$ of $10 \%$ trichloroacetic acid (Keay and Wildi, 1970). The reaction mixture was centrifuged at $8000 \times \mathrm{g}$ for $15 \mathrm{~min}$ and to the supernatant, $5 \mathrm{ml}$ of $0.4 \mathrm{~mol} / 1 \mathrm{Na}_{2} \mathrm{CO}_{3}$ and $1 \mathrm{ml}$ of 3-fold diluted Folin and Ciocalteau's phenol reagent, were added. The resulting solution was incubated at room temperature for $30 \mathrm{~min}$ and the absorbance of the blue color developed was read at $660 \mathrm{~nm}$ using a tyrosine standard (Lowry et al., 1951). One unit of enzyme activity was defined as the amount of enzyme that liberated $1 \mu \mathrm{g}$ of tyrosine from substrate (casein) per minute under assay conditions and reported in terms of protease activity per gram dry fermented substrate.

\section{Estimation of total soluble protein}

Protein concentration was determined by the method of Lowry et al. (1951) using bovine serum albumin as standard and was expressed as milligram protein per gram dry fermented substrate.

\section{Screening of fungal neutral protease producers}

The nine different Rhizopus strains were screened for neutral protease production by performing SSF using rice bran as substrate.

\section{Optimization of process parameters for neutral protease production}

The protocol adopted for the optimization of process parameters was to evaluate the effect of an individual parameter at a time and to incorporate it at the standard level before optimizing the next parameter.

\section{Optimization of incubation period}

The production profile of neutral protease was studied by conducting fermentation for different time intervals $(0,24,48,72,96,120,144$, and $168 \mathrm{~h}$ ). 


\section{Optimization of incubation temperature}

The inoculated substrates were incubated at different temperatures to determine the optimum fermentation temperature for neutral protease production $\left(10,25,30,37\right.$, and $\left.44^{\circ} \mathrm{C}\right)$.

\section{Optimization of initial moisture content}

Optimum initial moisture content for neutral protease production was determined by adjusting the initial moisture content of the fermentation substrate to varying levels $(37.5,44.4,50,54.5$, and $58.3 \%$ ).

\section{Effect of nutrient supplementation}

Effect of inorganic nitrogen supplements

Different sources of inorganic nitrogen $\left(\mathrm{NH}_{4} \mathrm{HCO}_{3}, \mathrm{NH}_{4} \mathrm{H}_{2} \mathrm{PO}_{4}, \quad\left(\mathrm{NH}_{4}\right)_{2} \mathrm{HPO}_{4}, \mathrm{NH}_{4} \mathrm{NO}_{3}\right.$, $\mathrm{NaNO}_{3}, \mathrm{KNO}_{3},\left(\mathrm{NH}_{4}\right)_{2} \mathrm{SO}_{4}$, and $\left.\mathrm{NH}_{4} \mathrm{Cl}\right)$ at $1 \%$ (w/w) were added to the fermentation medium to study its effect on enzyme production.

\section{Effect of organic nitrogen supplements}

Various organic nitrogen supplements (beef extract, casein, corn steep liquor, corn steep solids, malt extract, peptone, tryptone, and yeast extract) at a concentration of $1 \%(\mathrm{w} / \mathrm{w})$ were added to the fermentation media to study its effect on enzyme production.

\section{Effect of carbon supplements}

Influence of various carbon supplements on enzyme production was studied by adding different sugars (dextrose, maltose, sucrose, mannitol, sorbitol, xylose, lactose, and galactose) at $1 \%(\mathrm{w} / \mathrm{w})$ to the fermentation media.

\section{Solid-state fermentation under optimized conditions}

Solid-state fermentation of rice bran by the selected strain of Rhizopus was carried out under the optimized conditions of time, temperature, initial moisture content, and nutrient supplements.

\section{Partial purification of the enzyme}

The crude enzyme sample was separated into three fractions, based on the percentage saturation of ammonium sulphate, at $4{ }^{\circ} \mathrm{C}$ under constant stirring. The precipitated proteins were pelletized by centrifugation at $10000 \mathrm{x} g$ at $4{ }^{\circ} \mathrm{C}$ for $15 \mathrm{~min}$. These proteins were dissolved in $0.2 \mathrm{~mol} / \mathrm{l}$ phosphate buffer $(\mathrm{pH} 7.0)$ and stored at $4{ }^{\circ} \mathrm{C}$. The precipitate was dialyzed against the same buffer at
$4{ }^{\circ} \mathrm{C}$ for $24 \mathrm{~h}$ and the buffer was changed at regular intervals.

\section{Characterization of the partially purified enzyme}

The partially purified fraction showing highest specific activity was characterized by varying the parameters that influence enzyme activity.

\section{Substrate concentration}

The effect of assay substrate concentration on the activity of neutral protease was studied by using different concentrations of casein $(5,10$, $15,20,25$, and $30 \mathrm{mg} / \mathrm{ml})$.

\section{pH optimum}

The $\mathrm{pH}$ optimum of the neutral protease enzyme was determined by using buffer solutions of different $\mathrm{pH}$ (phosphate buffer 6.0, 6.5, 7.0, 7.5, 8.0, and tris-glycine buffer $8.5,9.0$ ) for enzyme assay. The buffers used were of the concentration $0.2 \mathrm{~mol} / \mathrm{l}$.

\section{Temperature optimum}

The influence of temperature on the activity of neutral protease was studied by incubating the assay reaction mixture at different temperatures $(30,35,40,45,50,55,60,65,70,75,80,85,90$, and $95^{\circ} \mathrm{C}$ ).

\section{Effect of enzyme modulators}

Different enzyme modulators (PMSF, EDTA, EGTA, DTT, $\mathrm{CuSO}_{4}, \mathrm{SDS}, \mathrm{CaCl}_{2}, \mathrm{MgSO}_{4}$, $\mathrm{MnSO}_{4}, \mathrm{FeSO}_{4}, \mathrm{ZnCl}_{2}$ ) of concentration $0.1 \mathrm{~mol} / \mathrm{l}$, was added to the assay mixture to study their effect on enzyme activity.

\section{RESULTS AND DISCUSSION}

The process parameters for the production of neutral protease by the highest protease-producing Rhizopus strain grown on rice bran substrate were done by the single-parameter mode. Fermentation was done under optimized conditions. The enzyme was partially purified and characterized. The results are presented and discussed below. 
$\underline{\text { Table } 1 \text { - Protease production by different strains of Rhizopus sp. on rice bran substrate. }}$

\begin{tabular}{lc}
\multicolumn{1}{c}{ Microorganism } & Protease activity (U/gds) \\
\hline R. oryzae 6431 & 32 \\
$R$. oryzae 3562 & 62 \\
$R$. oryzae 1891 & 31 \\
R. oryzae 1472 & 53 \\
R. oryzae 395 & 82 \\
R. oryzae 1526 & 69 \\
$R$. microsporus 3671 & 129 \\
$R$. oligosporus 5905 & 43 \\
$R$. oligosporus 2710 & 49 \\
\hline
\end{tabular}

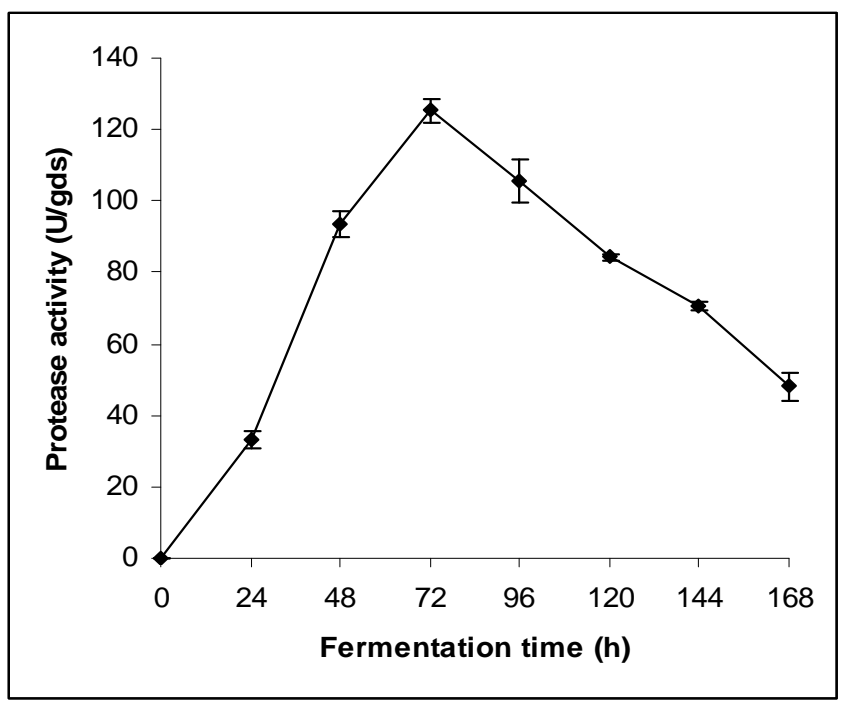

Figure 1 - Optimization of fermentation time for neutral protease production by R. microsporus NRRL 3671

\section{Screening of microorganisms}

$R$. microsporus NRRL 3671 proved to be the best strain for neutral protease production on rice bran substrate giving $129 \mathrm{U} / \mathrm{gds}$ of enzyme activity (Table 1). This Rhizopus strain was selected to optimize the process parameters for enzyme production by the SSF of rice bran.

\section{Fermentation time}

Maximum enzyme production was observed after $72 \mathrm{~h}$ of fermentation (Fig. 1). A gradual decrease in enzyme units was observed with increasing incubation time clearly suggesting the enzyme's role as a primary metabolite, being produced in the $\log$ phase of the growth of the fungus for utilization of nutrients (proteins) present in the solid substrate. The subsequent decrease in the enzyme units could probably be due to inactivation of the enzyme by other constituent proteases.

\section{Initial moisture content}

Initial moisture content is a crucial factor affecting the formation of products through solid-state fermentation. A moisture level of $44.4 \%$ was found to be optimum for neutral protease production (Fig. 2). Moisture content of 35-40\% facilitated neutral protease production by Aspergillus oryzae NRRL 2160 on a combined substrate of rice hulls and rice bran (Battaglino et al., 1991).

\section{Fermentation temperature}

R. microsporus NRRL 3671, being a mesophilic culture was found to be highly sensitive to temperature changes below and above its optimum for both enzyme production and growth (data not shown). Fermentation carried out at $30{ }^{\circ} \mathrm{C}$ was best suited for enzyme production (Fig. 2). 


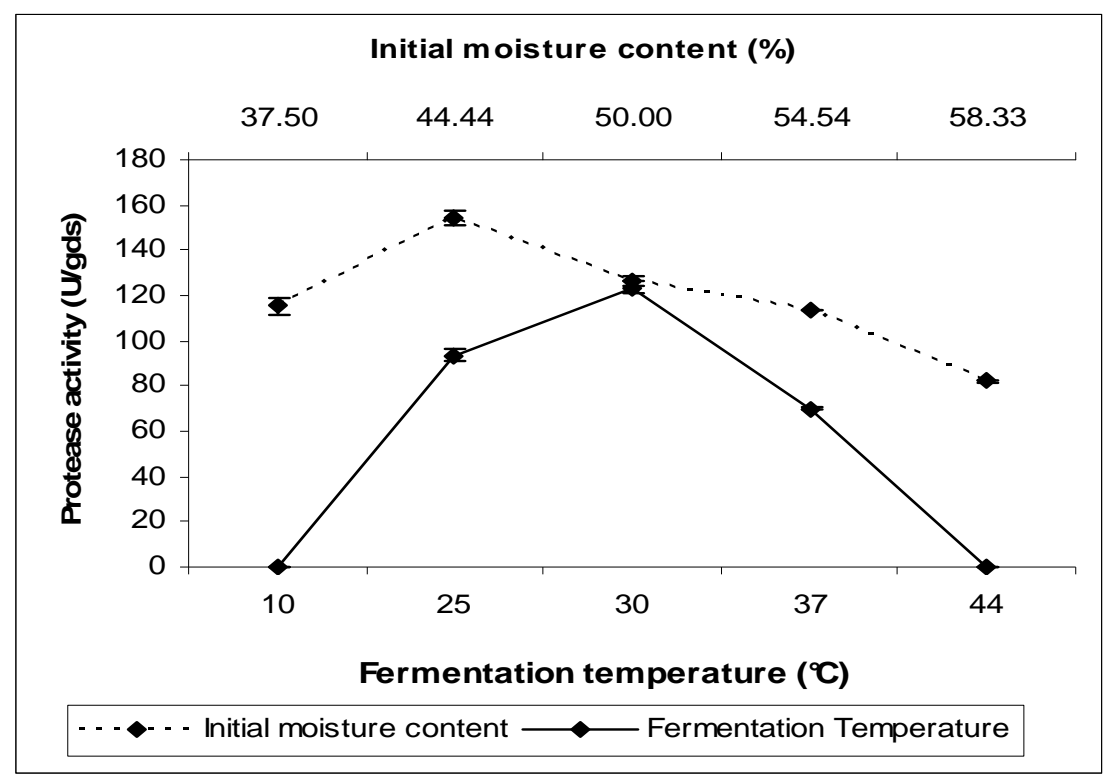

Figure 2 - Effect of initial moisture content and fermentation temperature on enzyme production by $R$. microsporus NRRL 3671

\section{Supplementation of nutrients}

Supplementation of the fermentation medium with $\mathrm{NH}_{4} \mathrm{HCO}_{3}$ was found to enhance enzyme production (Table 2). Since no other inorganic nitrogen compounds, e.g. $\mathrm{NH}_{4} \mathrm{NO}_{3}$ which has a higher molar concentration of nitrogen than $\mathrm{NH}_{4} \mathrm{HCO}_{3}$, enhanced protease production, the enhancing effect of $\mathrm{NH}_{4} \mathrm{HCO}_{3}$ can not be attributed to the nitrogen present in it, but could rather be due to the carbonate group. Carbonate as a constituent of the extraction buffer enhanced protease recovery from rice bran fermented by Aspergillus niger (Anupama and Ravindra, 2001). None of the organic nitrogen supplements enhanced protease production significantly, though casein showed a slightly promoting effect. Casein was found to be an inducer for protease synthesis by Bacillus licheniformis MIR 29 (Ferrero et al., 1996).

Almost all of the carbon supplements, especially sucrose, enhanced enzyme production. Sucrose probably provides the much required carbon in the carbohydrate-deficient rice bran substrate, which contains only about $1.3 \%$ of reducing sugars (The Wealth of India, 2001).

\section{Partial purification}

A better understanding of the function of enzyme could be determined by purification of enzyme (Sandhya et al., 2004). Partial purification of the enzyme by ammonium sulphate precipitation, followed by dialysis resulted in nearly a 3 -fold increase in the specific activity of the enzyme (Table 3).

Table 2 - Influence of various nutrient supplements on enzyme production by R. microsporus NRRL 3671

\begin{tabular}{l|c|l|c|c|c}
\hline $\begin{array}{c}\text { Inorganic } \\
\text { nitrogen } \\
\text { supplement }\end{array}$ & $\begin{array}{c}\text { Protease } \\
\text { activity (U/gds) }\end{array}$ & $\begin{array}{c}\text { Organic nitrogen } \\
\text { supplement }\end{array}$ & $\begin{array}{c}\text { Protease } \\
\text { activity } \\
\text { (U/gds) }\end{array}$ & $\begin{array}{c}\text { Carbon } \\
\text { supplement }\end{array}$ & $\begin{array}{c}\text { Protease } \\
\text { activity (U/gds) }\end{array}$ \\
\hline $\mathrm{NH}_{4} \mathrm{HCO}_{3}$ & 195 & Beef extract & 188 & Glucose & 266 \\
$\mathrm{NH}_{4} \mathrm{H}_{2} \mathrm{PO}_{4}$ & 65 & Casein & 214 & Maltose & 272 \\
$\left(\mathrm{NH}_{4}\right)_{2} \mathrm{HPO}_{4}$ & 117 & Corn steep liquor & 202 & Sucrose & 292 \\
$\mathrm{NH}_{4} \mathrm{NO}_{3}$ & 71 & Corn steep solids & 193 & Mannitol & 235 \\
$\mathrm{NaNO}_{3}$ & 150 & Malt extract & 197 & Sorbitol & 237 \\
$\mathrm{KNO}_{3}$ & 130 & Peptone & 205 & Xylose & 197 \\
$\left(\mathrm{NH}_{4}\right)_{2} \mathrm{SO}_{4}$ & 79 & Tryptone & 207 & Lactose & 226 \\
$\mathrm{NH}_{4} \mathrm{Cl}$ & 27 & Yeast Extract & 200 & Galactose & 229 \\
$\mathrm{Control}$ & 154 & Control & 194 & Control & 210 \\
\hline
\end{tabular}


$\underline{\text { Table } 3 \text { - Increase in specific activity of neutral protease with partial purification }}$

\begin{tabular}{lc}
\hline \multicolumn{1}{c}{ Enzyme fraction } & Specific activity (U/mg) \\
\hline Crude enzyme & 5.7 \\
$20-40 \%$ & 6.3 \\
$40-60 \%$ & 17 \\
$60-80 \%$ & 16 \\
\hline
\end{tabular}

\section{Enzyme characterization}

\section{Substrate concentration}

The assay substrate, casein, when used at increasing concentrations resulted in the saturation of the enzyme (Fig. 3). From Lineweaver-Burk plot, the $\mathrm{K}_{\mathrm{m}}$ and $\mathrm{V}_{\max }$ of the reaction was found to be 2.6 and $19.9 \mathrm{mg} / \mathrm{min}$, respectively (data not shown).

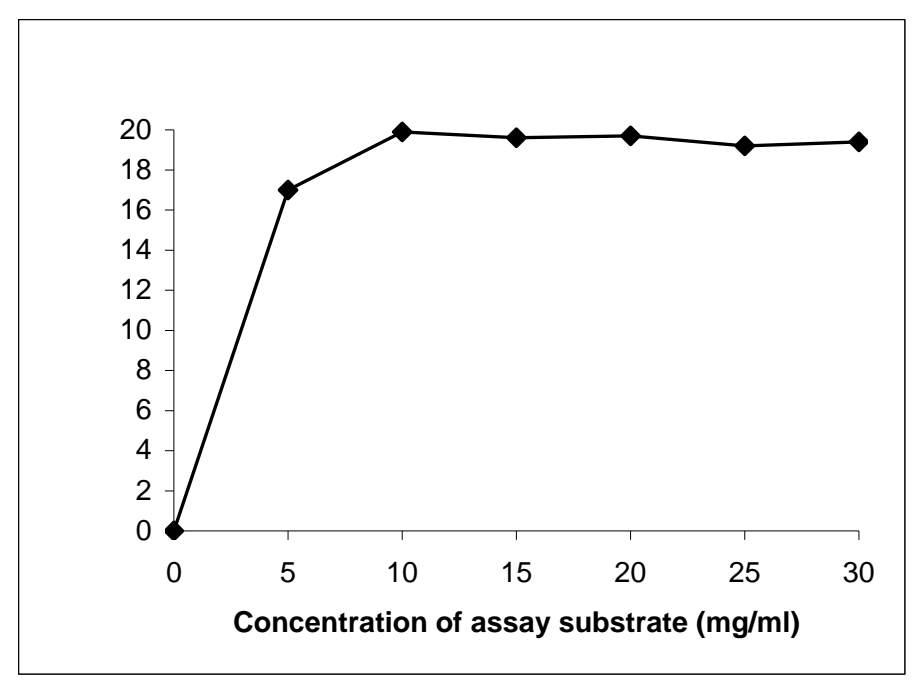

Figure 3 - Reaction of the partially purified neutral protease of R. microsporus NRRL 3671 with its substrate, casein, and attainment of saturation at a casein concentration of $10 \mathrm{mg} / \mathrm{ml}$

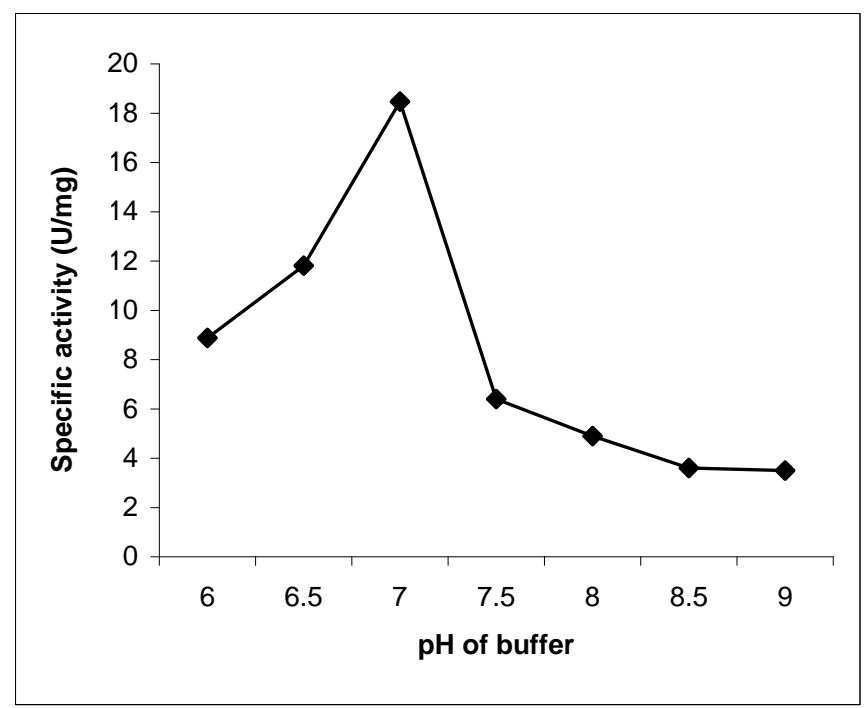

Figure 4 - pH curve of the partially purified neutral protease of R. microsporus NRRL 3671 
pH

A gradual increase in specific activity to reach a peak at $\mathrm{pH} 7.0$ was then followed by a sharp decline as shown in fig. 4 indicating the enzyme's instability at any $\mathrm{pH}$ other than its optimum, viz. 7.0. A neutral metalloprotease from Staphylococcus epidermidis also has $\mathrm{pH}$ optima in the range 5.0-7.0 (Teufel and Gotz, 1993).

\section{Temperature}

The partially purified enzyme was stable at a temperature range of $50-60{ }^{\circ} \mathrm{C}$. The enzyme activity gradually increased with increasing temperature, followed by a steep decrease at temperatures above $60{ }^{\circ} \mathrm{C}$ (Fig. 5). A neutral metalloprotease exhibiting maximal activity at a temperature of $60{ }^{\circ} \mathrm{C}$ was purified from Aspergillus fumigatus (Markaryan et al., 1994).

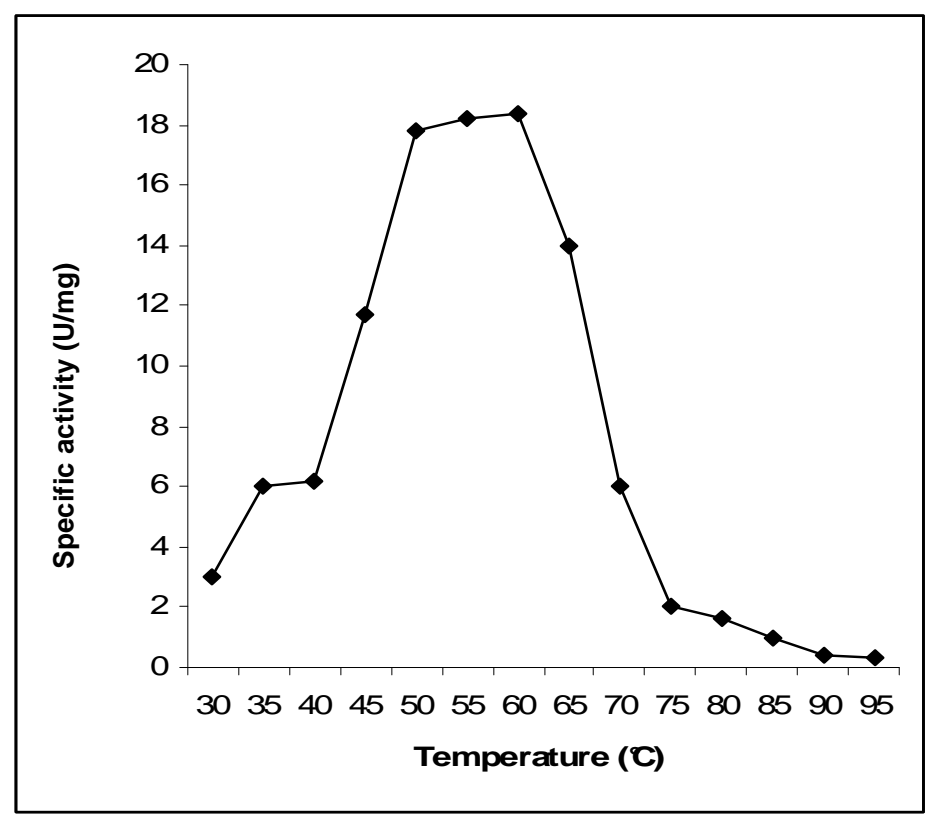

Figure 5 - Temperature curve of the partially purified neutral protease of $R$. microsporus NRRL 3671

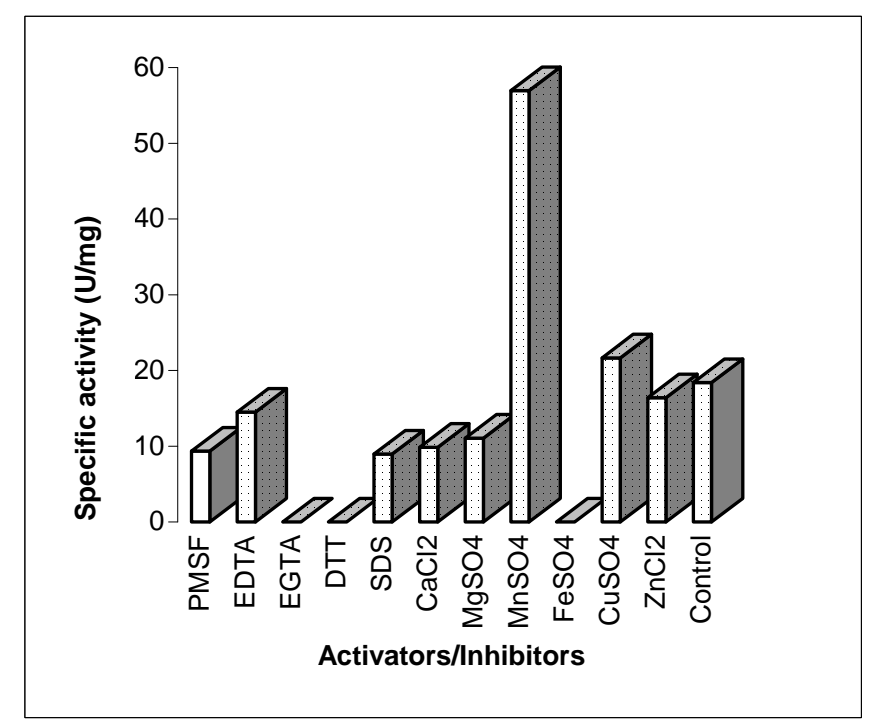

Figure 6 - Effect of enzyme modulators on neutral protease activity after partial purification 


\section{Effect of activators/inhibitors}

The effect of various activators and inhibitors at $0.1 \mathrm{~mol} / \mathrm{l}$ concentration showed that the neutral protease is a metalloenzyme requiring $\mathrm{Mn}^{2+}$ for its activity (Fig. 6). The inhibition of enzyme activity by EGTA, EDTA also proved this. The enzyme was comparatively resistant to PMSF and SDS, but highly sensitive to DTT. $\mathrm{Cu}^{2+}$ slightly enhanced enzyme activity, but addition of other metal ions such as $\mathrm{Ca}^{2+}, \mathrm{Mg}^{2+}, \mathrm{Fe}^{2+}$, and $\mathrm{Zn}^{2+}$ did not improve enzyme activity. A neutral protease from Bacillus subtilis that was activated by $\mathrm{Mn}^{2+}$ and a few other metal ions and susceptible to metal chelators such as EDTA was described by Yang et al. (2000), while the production of a neutral metalloprotease by Bacillus thuringiensis var. kurstaki was dependent upon the presence of $\mathrm{Mn}^{2+}$ in the fermentation medium ( $\mathrm{Li}$ and Yousten, 1975).

\section{ACKNOWLEDGEMENTS}

The authors thank CSIR, India for providing financial support under the networked Task Force Project (CMM 0006). A. Sumantha gratefully acknowledges a Junior Research Fellowship from CSIR, India.

\section{RESUMO}

Farelo de arroz foi utilizado como substrato para seleção de nove linhagens de Rhizopus sp. com vistas a produção de protease neutra. A linhagem que apresentou maior produtividade da enzima foi Rhizopus microsporus NRRL 3671, sendo utilizada na otimização dos parâmetros do processos e produção da enzima. As condições otimizadas para produção da enzima foram $44 \%$ de umidade inicial, temperatura de $30^{\circ} \mathrm{C}$ e $72 \mathrm{~h}$ de fermentação.A suplementação do farelo de arroz com uma fonte de carbono favoreceu a produção da enzima, porém a adição de caseína resultou em um aumento marginal do rendimento em protease. Condições otimizadas foram utilizadas para obtenção do extrato cru da enzima que foi parcialmente purificado por precipitação e diálise. A enzima purificada teve sua atividade incrementada 3 vezes. A enzima foi classificada como metalo-protease, sendo ativada pelo $\mathrm{Mn}^{2+}$, sendo que sua atividade máxima foi obtida a temperatura de $60^{\circ} \mathrm{C}$ e a pH 7.0.

\section{REFERENCES}

Anupama and Ravindra, P. (2001), Studies on production of single cell protein by Aspergillus niger in solid state fermentation of rice bran. Braz. Arch. Biol. Tech., 44, 79-88.

Battaglino, R. A.; Huergo, M.; Pilosof, A. M. R. and Bartholomai, G. B. (1991), Culture requirements for the production of protease by Aspergillus oryzae in solid state fermentation. Appl. Microbiol. Biotechnol., 35, 292-296.

Chou, C. C. and Rwan, J. H. (1995), Mycelial propagation and enzyme production in koji prepared with Aspergillus oryzae on various rice extrudates and steamed rice. J. Ferment. Bioengg., 79, 509-512.

Couri, S.; Terzi, S. C.; Pinto, G. A. S.; Freitas, S. P. and Costa, A. C. A. (2000), Hydrolytic enzyme production in solid-state fermentation by Aspergillus niger 3T5B8. Process Biochem., 36, 255-261.

Fernandez-Lahore, H. M.; Fraile, E. R. and Cascone, O. (1998), Acid protease recovery from a solid-state fermentation system. J. Biotechnol., 62, 83-93.

Ferrero, M. A.; Castro, G. R.; Abate, C. M.; Baigori, M. D. and Sineriz, F. (1996), Thermostable alkaline proteases of Bacillus licheniformis MIR 29: isolation, production and characterization. Appl. Microbiol. Biotechnol., 45, 327-332.

Ikasari, L. and Mitchell, D. A. (1996), Leaching and characterization of Rhizopus oligosporus acid protease from solid-state fermentation. Enzyme Microb. Technol., 19, 171-175.

Ikasari, L. and Mitchell, D. A. (1998), Mimicking gas and temperature changes during enzyme production by Rhizopus oligosporus in solid-state fermentation. Biotechnol. Lett., 20, 349-353.

Keay, L. and Wildi, B. S. (1970), Proteases of the genus Bacillus. I. Neutral proteases. Biotechnol. Bioengg., 12, 179-212.

Li, E. and Yousten, A. A. (1975), Metalloprotease from Bacillus thuringiensis, Appl. Microbiol., 30, 354-361.

Lowry, O. H.; Rosebrough, N. J.; Farr, A. L. and Randall, R. J. (1951), Protein measurement with Folin phenol reagent. J. Biol. Chem., 193, 265- 275.

Manonmani, H. K. and Joseph, R. (1993), Purification and properties of an extracellular proteinase by Trichoderma koningii. Enzyme Microb. Technol., 15, 624-628.

Markaryan, A.; Morozova, I.; Yu, H. and Kolaitukudy, P. E. (1994), Purification and characterization of an elastinolytic metalloprotease from Aspergillus fumigatus and immunoelectron microscopic evidence of secretion of this enzyme by the fungus invading the murine lung. Infec. Immun., 62, 2149-2157.

Rao, P. V.; Jayaraman, K. and Lakshmanan, C. M. (1993a), Production of lipase by Candida rugosa in solid-state fermentation. 1: determination of significant process variables. Process Biochem., 28, 385-389. 
Rao, P. V.; Jayaraman, K. and Lakshmanan, C. M. (1993b), Production of lipase by Candida rugosa in solid-state fermentation. 2: Medium optimization and effect of aeration. Process Biochem., 28, 391-395.

Sandhya, C.; Sumantha, A. and Pandey, A. (2004), Proteases. In: Pandey, A.; Webb, C.; Soccol, C. R. and Larroche, C. (Eds.). Enzyme technology. New Delhi: Asiatech Publishers Inc. pp. 312-325.

Sandhya, C.; Sumantha, A.; Szakacs, G. and Pandey, A. (2005), Comparative evaluation of neutral protease production by Aspergillus oryzae in submerged and solid-state fermentation. Process Biochem., 40, 2689-2694.

Tani, Y.; Vongsuvanlert, V. and Kumnuanta, J. (1986), Raw cassava starch-digestive glucoamylase of Aspergillus sp. N-2 isolated from cassava chips. $J$. Ferment. Technol., 64, 405-410.

Teufel, P. and Gotz, F. (1993), Characterization of an extracellular metalloprotease with elastase activity from Staphylococcus epidermidis. J. Bacteriol., 175, 4218-4224.

The Wealth of India: a dictionary of Indian raw materials and industrial products (2001), Raw materials. New Delhi: NISCOM. v. 7: N-Pe. pp. 110191.

Yang, J. K.; Shih, I. L.; Tzeng, Y. M. and Wang, S. L. (2000), Production and purification of protease from a Bacillus subtilis that can deproteinize crustacean wastes. Enz. Microb. Technol., 26, 406-413.

Received: March 04, 2005; Revised: December 12, 2005; Accepted: July 12, 2006. 